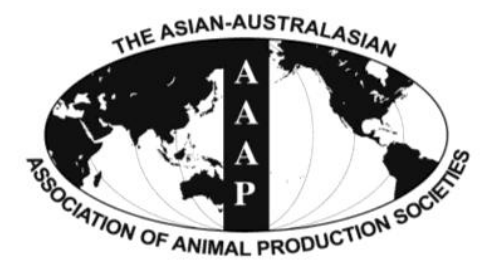

Asian Australas. J. Anim. Sci.

Vol. 26, No. 6 : 879-885 June 2013

http://dx.doi.org/10.5713/ajas.2012.12675

www.ajas.info

pISSN 1011 -2367 elSSN 1976-5517

\title{
Effects of Short-term Feeding Magnesium before Slaughter on Blood Metabolites and Postmortem Muscle Traits of Halothane-carrier Pigs
}

\author{
Jing Chen, XianJun Liu* and LianQuan Bian \\ College of Animal Science and Veterinary Medicine, Shenyang Agricultural University, 110866, China
}

\begin{abstract}
Fifty-four, mixed-sex, halothane-carrier crossbred (Yorkshire $\times$ Landrace) pigs with an average initial BW of $108.2 \pm 0.8$ $\mathrm{kg}$ were randomly allotted to one of three dietary treatments for $5 \mathrm{~d}$ before slaughter: i) a control corn-soybean meal finisher diet devoid of supplemental magnesium; ii) a diet supplemented with $1.5 \mathrm{~g} / \mathrm{kg}$ of elemental $\mathrm{Mg}$ from magnesium acetate; and iii) a diet supplemented with $1.5 \mathrm{~g} / \mathrm{kg}$ of elemental $\mathrm{Mg}$ from magnesium sulfate heptahydrate. Serum creatine kinase (CK), lactate and glucose were analyzed at slaughter. Muscles from longissimus (LM) were packaged and stored to simulate display storage for muscle lactate and glycogen determinations at $0,1,2,3$, and $4 \mathrm{~d}$. Mg supplementation reduced ( $\mathrm{p}<0.05)$ serum $\mathrm{CK}$ and lactate concentration, but had no effect $(p>0.05)$ on serum glucose. Daily change of muscle lactate concentration linearly increased $(p<0.01)$, while glucose concentration linearly decreased $(\mathrm{p}<0.05)$ as storage time increased in all treatments. However, dietary $\mathrm{Mg}$ acetate and $\mathrm{Mg}$ sulfate supplementation in pigs elevated $(\mathrm{p}<0.05)$ muscle glycogen and reduced $(\mathrm{p}<0.05)$ muscle lactate concentrations, especially during the first $2 \mathrm{~d}$ of display, compared with pigs fed the control diet. This study suggests that short-term feeding of magnesium acetate and magnesium sulfate to heterozygous carriers of the halothane gene has beneficial effects on stress response and pork quality by improving blood and muscle biochemical indexes. (Key Words: Magnesium, Halothane-carrier Pigs, Blood Stress Index, Postmortem Metabolism)
\end{abstract}

\section{INTRODUCTION}

The pre-slaughter handling of fattening pigs is one of the most stressful events and it has an important effect on the final carcass and pork quality (Gispert et al., 2000; Panella-Riera et al., 2008). It includes mixing unfamiliar animals, fasting, loading, transport, abattoir lairage and the stunning procedure. All of these are stressful factors which sometimes are difficult to alleviate. Acute pre-slaughter stress may result in an increase in drip loss and paler meat (Panella-Riera et al., 2008), producing pale, soft and exudative (PSE) meat. The existence of PSE meat also has a genetic origin related to the halothane gene (n) which is also known as RYR1 gene. In fact, homozygous halothane positive (nn) and heterozygous (Nn) pigs have an abnormality in their muscle metabolism that makes them particularly sensitive to acutely stressful stimuli, causing a higher incidence of PSE meat (Jensen and Barton-Gade, 1985; Oliver et al., 1993; Fàbrega et al., 2002). This

\footnotetext{
* Corresponding Author: XianJun Liu. Tel: +86-24-88487230, Fax:+86-24-88487156, E-mail: lchenj@163.com Submitted Dec. 6, 2012; Accepted Jan. 29, 2013; Revised Mar. 3, 2013
}

abnormality does not exist in halothane negative (NN) pigs. Fàbrega et al. (2004) observed that Nn pigs had higher heart rate and CPK than NN pigs, which indicated that halothane carriers may be more responsive to stressful situations and this could compromise the welfare of those individuals.

Research has confirmed that stress associated effects on animal blood and muscle biochemical traits may be improved by including feed components such as $\mathrm{Mg}$ in the diet of pigs, especially those with the halothane gene. Magnesium ( $\mathrm{Mg}$ ) is reported to be an important cofactor in many enzymatic reactions involved in energy and protein metabolism and can counteract catecholamine effects in stress situations (Kietzmann and Jablonski, 1985; Sahin et al., 2005). In fact, short-term supplemental $\mathrm{Mg}$ has been reported to alleviate the acute stress response resulting from handling prior to slaughter (Kuhn et al., 1981; Peeters et al., 2005) and improve pork quality (Caine et al., 2000; Hamilton et al., 2002; Frederick et al., 2006; Alonso et al., 2012). However, different results have been obtained when comparing the effect of $\mathrm{Mg}$ supplementation to carriers $(\mathrm{Nn})$ of the halothane gene (Caine et al., 2000; Apple et al., 2002), which may be due to the difference of $\mathrm{Mg}$ sources 
(organic $\mathrm{Mg}$ or inorganic $\mathrm{Mg}$ ).

Therefore, the aim of this study was to assess the effect of short-term supplementation of swine finishing diets with different $\mathrm{Mg}$ sources (magnesium acetate and magnesium sulfate) on serum biochemical traits and muscle post mortem changes of heterozygous pigs of the Halothane gene under generally commercial conditions.

\section{MATERIALS AND METHODS}

\section{Halothane genotype determination}

The halothane genotype was determined by using a biopsy sample of blood obtained through an ear vein puncture by DNA tests (Blood Genome DNA Extraction Kit and TaKaRa PCR Amplification Kit, TaKaRa Biotechnology (Dalian) Co., Ltd.) according to Fujii et al. (1991) when the pigs were approximately $40 \mathrm{~kg}$ live weight. Pigs selected in experiment were all heterozygous pigs (halothane-carrier pigs).

\section{Animals and treatments}

Fifty-four, mixed-sex, halothane-carrier crossbred (Yorkshire $\times$ Landrace) pigs with an average initial BW of $108.2 \pm 0.8 \mathrm{~kg}$ were randomly allotted to one of three dietary treatments for $5 \mathrm{~d}$ before slaughter: i) a control cornsoybean meal finisher diet devoid of supplemental magnesium; ii) a diet supplemented with $1.5 \mathrm{~g} / \mathrm{kg}$ of elemental $\mathrm{Mg}$ from magnesium acetate $(\mathrm{MgAc}, 11.2 \% \mathrm{Mg})$; and iii) a diet supplemented with $1.5 \mathrm{~g} / \mathrm{kg}$ of elemental $\mathrm{Mg}$ from magnesium sulfate heptahydrate $\left(\mathrm{MgSO}_{4} \cdot 7 \mathrm{H}_{2} \mathrm{O}, 9.6 \%\right.$ $\mathrm{Mg}$ ). Each treatment was replicated six pens with three pigs per pen.

\section{Housing and feeding}

Animals were housed in buildings on partially slatted concrete floors, and each pen was $1.80 \times 3.00 \mathrm{~m}$ with a floor space allowance of $1.8 \mathrm{~m}^{2} / \mathrm{pig}$. The environment within the building was controlled using a thermostat and fan ventilation (the building temperature remained between $19^{\circ} \mathrm{C}$ and $20^{\circ} \mathrm{C}$, and the relative humidity remained between $50 \%$ and $55 \%$ ).

The finisher diet used in the experiment was formulated to meet or exceed NRC (1998) requirements for growingfinishing swine. Feed in the form of a standard pelleted finisher diet (Control diet; Table 1) was offered ad libitum and water was freely available from a nipple drinker.

\section{Slaughter, fabrication and storage}

Pigs were transported $(15 \pm 5 \mathrm{~min})$ to a commercial abattoir over a distance of approximately $7 \mathrm{~km}$ and were kept overnight in lairage (time off feed-12 h). Slaughter took place on the same day. Pigs were stunned electrically (240 V, $800 \mathrm{~Hz}$ for $2 \mathrm{~s}$ ) and killed by exsanguinations. At
Table 1.Composition of basal diets, as-fed basis

\begin{tabular}{|c|c|}
\hline Item & Control diet \\
\hline \multicolumn{2}{|l|}{ Ingredient (\%) } \\
\hline Corn & 71.0 \\
\hline Soybean meal, $48 \% \mathrm{CP}$ & 15.1 \\
\hline Corn germ meal & 6.0 \\
\hline Corn distiller dried drains & 4.92 \\
\hline Limestone & 1.8 \\
\hline Calcium hydrogen phosphate & 0.3 \\
\hline Salt & 0.3 \\
\hline L-lysine $\cdot \mathrm{HCl}$ & 0.2 \\
\hline Trace mineral salt ${ }^{1}$ & 0.24 \\
\hline Vitamin mix ${ }^{2}$ & 0.14 \\
\hline \multicolumn{2}{|l|}{ Composition } \\
\hline ME (Mcal/kg) & 3.15 \\
\hline Crude protein $(\%)$ & 15.22 \\
\hline Calcium $(\%)$ & 0.84 \\
\hline Total phosphorous (\%) & 0.45 \\
\hline Lysine $(\%)$ & 0.80 \\
\hline Methionine (\%) & 0.23 \\
\hline Methionine and cysteine (\%) & 0.50 \\
\hline Threonine $(\%)$ & 0.60 \\
\hline Tryptophan (\%) & 0.16 \\
\hline Magnesium (Mg, \%) & 0.11 \\
\hline \multicolumn{2}{|c|}{$\begin{array}{l}{ }^{1} \text { Contains per kg: } \mathrm{Cu}, 200 \mathrm{mg} \text {; Fe, } 120 \mathrm{mg} \text {; } \mathrm{Zn}, 150 \mathrm{mg} \text {; Mn, } 30 \mathrm{mg} \text {; } \text {, } \\
0.82 \mathrm{mg} \text {; Se, } 0.3 \mathrm{mg} \text {. } \\
{ }^{2} \text { Contains per kg: Vit A, } 9,500 \mathrm{IU} \text {; Vit } \mathrm{D}_{3}, 3,000 \mathrm{IU} \text {; Vit E, } 20 \mathrm{mg} \text {; Vit } \mathrm{K}_{3} \text {, } \\
8 \mathrm{mg} \text {; Vit } \mathrm{B}_{1}, 1.52 \mathrm{mg} \text {; Vit } \mathrm{B}_{2}, 15 \mathrm{mg} \text {; Vit } \mathrm{B}_{6}, 3 \mathrm{mg} \text {; Vit B } \mathrm{B}_{12}, 0.05 \mathrm{mg} \text { - }- \\
\text { pantothenic acid, } 50 \mathrm{mg} \text {; Niacin, } 80 \mathrm{mg} \text {; Folic acid, } 0.95 \mathrm{mg} \text {; Biotin, } 0.2 \\
\text { mg; Choline chloride, } 160 \mathrm{mg} \text {. }\end{array}$} \\
\hline \multicolumn{2}{|c|}{$\begin{array}{l}\text { Crude protein, calcium and total phosphorus are analyzed values. Others } \\
\text { are calculated values. }\end{array}$} \\
\hline
\end{tabular}

slaughter, blood samples $(10 \mathrm{ml})$ and $\mathrm{LM}$ from the left side of each carcass of each pig were collected and transported to the Animal Production Laboratory of Shenyang Agricultural University. Blood for the analysis of serum creatine kinase (CK), glucose, lactate was transferred into a plain glass storage tube and was kept on ice until centrifugation. Tubes were centrifuged at $1,500 \times \mathrm{g}$ at $4^{\circ} \mathrm{C}$ for $20 \mathrm{~min}$, and serum was stored at $-20^{\circ} \mathrm{C}$ before analysis. The LM was sectioned into chops for muscle lactate, glycogen. All packages were placed on an absorbent pad within a styrofoam tray, wrapped with an oxygen-permeable film and stored in a refrigerator at $4 \pm 1^{\circ} \mathrm{C}$ in the presence of fluorescent lighting to simulate retail display during $5 \mathrm{~d}$ of storage time. Muscle chemical analysis was performed on $\mathrm{d}$ $0,1,2,3$ and 4 of storage.

\section{Chemical analyses}

Serum glucose concentrations were determined by using a spectrophotometric procedure in commercially available kit (Sigma Chemical Co., St. Louis, MO, USA). Serum lactate concentrations were determined spectrophotometrically 
Table 2. The effect of dietary magnesium supplementation on serum creatine kinase, glucose, and lactate concentrations in pigs at slaughter ${ }^{1}$

\begin{tabular}{|c|c|c|c|c|c|}
\hline \multirow{2}{*}{ Item } & \multicolumn{3}{|c|}{ Treatment } & \multirow{2}{*}{$\begin{array}{c}\text { SEM } \\
(n=6)\end{array}$} & \multirow{2}{*}{ Sig. } \\
\hline & Control & Magnesium acetate & Magnesium sulfate & & \\
\hline$\overline{\mathrm{CK}^{1}(\mathrm{IU} / \mathrm{L})}$ & $65.21^{\mathrm{a}}$ & $48.87^{\mathrm{b}}$ & $50.2^{b}$ & 3.52 & $*$ \\
\hline Lactate $(\mathrm{mmol} / \mathrm{L})$ & $12.34^{\mathrm{a}}$ & $9.32^{b}$ & $9.08^{b}$ & 0.53 & $* *$ \\
\hline Glucose $(\mathrm{mg} / \mathrm{L})$ & $1,802.3$ & $1,880.6$ & $1,839.7$ & 45.79 & NS \\
\hline
\end{tabular}

${ }^{a-b}$ Least square means within a row with different superscripts (a-b) are significantly different (NS = Not significant, $\mathrm{p}<0.05$ and $\left.* * \mathrm{p}<0.01\right)$

${ }^{1} \mathrm{CK}=$ Creatine kinase.

by using the procedure of Brandt et al. (1980), modified to use microtiter plates, whereas serum CK concentrations were determined using a spectrophotometric procedure from commercially available kits (Sigma Chemical Co., St. Louis, MO, USA).

The muscle lactate concentrations were measured by using a commercially available lactate kit (826-A; SigmaAldrich Co.) by the change in spectrophotometric absorbance of NADH at $340 \mathrm{~nm}$ (Bergmeyer, 1974). Glycogen concentrations were determined simultaneously by the change in absorbance at $340 \mathrm{~nm}$ (Dalrymple and Hamm, 1973).

\section{Statistical analysis}

All experimental data were analyzed by the General Linear Model (GLM) procedure of SAS (SAS Inst., Inc., Cary, NC, 1996), with dietary treatment and storage period as the main effect and also their interaction in the model. Differences between treatments were determined by using Duncan's test. Polynomial contrasts (linear or quadratic) were conducted to evaluate the effect of display time. A level of $p<0.05$ was set as the criterion for statistical significance. A pen was the experimental unit.

\section{RESULTS}

\section{Serum CK, lactate and glucose concentrations}

The results of serum CK, glucose, and lactate are presented in Table 2. Pigs fed diets supplemented with $\mathrm{Mg}$ acetate and $\mathrm{Mg}$ sulfate had lower $(\mathrm{p}<0.05)$ serum CK and lactate concentrations compared to pigs fed the control diet. However, there were no differences $(p>0.05)$ in serum glucose concentrations between pigs fed the control diet compared with pigs fed the different $\mathrm{Mg}$ diets.

\section{Muscle lactate and glycogen concentrations}

Muscle lactate data are presented in Table 3. Dietary $\mathrm{Mg}$ supplementation $(p<0.05)$ and storage period $(p<0.05)$ influenced muscle lactate, but no interaction occurred ( $\mathrm{p}>0.05$ ). Pigs that were fed the $\mathrm{Mg}$ acetate and $\mathrm{Mg}$ sulfate supplemented diets had lower muscle lactate at $0(\mathrm{p}<0.05)$ and $1(\mathrm{p}<0.01) \mathrm{d}$ of storage compared with pigs that were fed the control diet. There were no differences $(p>0.05)$ in muscle lactate concentrations between pigs fed the control diet compared with pigs fed the different magnesium diets from 2 to $4 \mathrm{~d}$ of storage. Daily change (0 to $4 \mathrm{~d}$ of storage) of muscle lactate showed significantly linear increase in the control group $(\mathrm{p}<0.01), \mathrm{Mg}$ acetate diet treatment $(\mathrm{p}<0.01)$, and $\mathrm{Mg}$ sulfate diet treatment $(\mathrm{p}<0.01)$. There were also significant $(\mathrm{p}<0.01)$ quadratic increases in the control group $(\mathrm{p}<0.01)$.

Muscle glycogen data are presented in Table 4. Dietary $\mathrm{Mg}$ supplementation $(\mathrm{p}<0.05)$ and storage period $(\mathrm{p}<0.05)$ influenced muscle glycogen, but no interaction occurred ( $p>0.05$ ). Pigs fed the $\mathrm{Mg}$ acetate and $\mathrm{Mg}$ sulfate supplemented diets had higher $(\mathrm{p}<0.05)$ muscle glycogen concentrations compared to pigs fed the control diet on 0 and $1 \mathrm{~d}$ of storage. Daily change ( 0 to $4 \mathrm{~d}$ of storage) of muscle glycogen showed significantly linear decrease in the control group $(\mathrm{p}<0.01), \mathrm{Mg}$ acetate diet treatment $(\mathrm{p}<0.05)$

Table 3. The effect of dietary magnesium supplementation on muscle lactate following 0 to $4 \mathrm{~d}$ of storage at $4{ }^{\circ} \mathrm{C}(\mathrm{mmol} / \mathrm{g}$ )

\begin{tabular}{|c|c|c|c|c|c|}
\hline \multirow{2}{*}{ Day } & \multicolumn{3}{|c|}{ Treatment } & \multirow{2}{*}{$\begin{array}{c}\text { SEM } \\
(n=6)\end{array}$} & \multirow{2}{*}{ Sig. } \\
\hline & Control & Magnesium acetate & Magnesium sulfate & & \\
\hline$\overline{0}$ & $0.55^{\mathrm{a}}$ & $0.35^{\mathrm{b}}$ & $0.36^{\mathrm{b}}$ & 0.03 & $*$ \\
\hline 1 & $0.92^{\mathrm{a}}$ & $0.67^{\mathrm{b}}$ & $0.70^{\mathrm{b}}$ & 0.07 & $* *$ \\
\hline 2 & 1.97 & 1.81 & 1.92 & 0.17 & NS \\
\hline 3 & 2.12 & 2.06 & 2.13 & 0.10 & NS \\
\hline 4 & 2.37 & 2.32 & 2.40 & 0.15 & NS \\
\hline Mean & 1.59 & 1.44 & 1.50 & 0.12 & \\
\hline Linear & $* *$ & $* *$ & $* *$ & & \\
\hline Quadratic & $* *$ & NS & NS & & \\
\hline
\end{tabular}


Table 4. The effect of dietary magnesium supplementation on muscle glycogen following 0 to $4 \mathrm{~d}$ of storage at $4{ }^{\circ} \mathrm{C}(\mathrm{mg} / \mathrm{g})$

\begin{tabular}{|c|c|c|c|c|c|}
\hline \multirow{2}{*}{ Day } & \multicolumn{3}{|c|}{ Treatment } & \multirow{2}{*}{$\begin{array}{c}\text { SEM } \\
(\mathrm{n}=18)\end{array}$} & \multirow{2}{*}{ Sig. } \\
\hline & Control & Magnesium acetate & Magnesium sulfate & & \\
\hline$\overline{0}$ & $2.63^{\mathrm{b}}$ & $3.12^{\mathrm{a}}$ & $3.05^{\mathrm{a}}$ & 0.18 & $*$ \\
\hline 1 & $1.87^{\mathrm{b}}$ & $2.04^{\mathrm{a}}$ & $1.98^{\mathrm{a}}$ & 0.11 & $*$ \\
\hline 2 & 0.90 & 0.95 & 0.89 & 0.04 & NS \\
\hline 3 & 0.65 & 0.75 & 0.62 & 0.04 & NS \\
\hline 4 & 0.35 & 0.36 & 0.43 & 0.02 & NS \\
\hline Mean & 1.38 & 1.40 & 1.39 & 0.10 & \\
\hline Linear & $* *$ & $*$ & $*$ & & \\
\hline Quadratic & $*$ & NS & ** & & \\
\hline
\end{tabular}

and $\mathrm{Mg}$ sulfate diet treatment $(\mathrm{p}<0.05)$. There were also significant quadratic decrease in the control $(\mathrm{p}<0.05)$ and $\mathrm{Mg}$ sulfate diet treatment $(\mathrm{p}<0.01)$.

\section{DISCUSSION}

\section{Effect of magnesium supplementation on serum metabolites}

Stress assessment using blood indices is likely to present some problems when interpreting the results, because stress systems have been said to be affected differently by the same quality of stressor (Schrader and Ladewig, 1999). Creatine kinases (CK) and lactate level are commonly used as indicators of muscle damage (Ryan, et al., 2009) and are released into the blood under certain circumstances such as slaughter stress. $\mathrm{Mg}$ is reported to be an important cofactor in many enzymatic reactions involved in energy and protein metabolism and can counteract catecholamine effects in stress situations, and thus decrease the acute stress response resulting from handling prior to slaughter (Panella-Riera et al., 2008). In the present study, the observation that dietary $\mathrm{Mg}$ supplementation, whether $\mathrm{Mg}$ acetate or $\mathrm{Mg}$ sulfate, significantly reduced serum $\mathrm{CK}$ and lactate concentrations at slaughter is consistent with Otten et al. (1993, 1995), which reported that dietary $\mathrm{Mg}$ fumarate lowered blood lactate concentrations at slaughter during the growing and finishing phase, which indicated that these pigs fed $\mathrm{Mg}$ supplementation fought less and were more relaxed. However, Peeters et al. (2006) confirmed that blood $\mathrm{CK}$ concentrations did not differ between the $\mathrm{Mg}$ acetate supplemented and nonsupplemented group through drinking water for Nn pigs. Apple et al. (2005) and Geesink et al. (2004) also reported that $\mathrm{Mg}$ mica and $\mathrm{Mg}$ acetate did not affect blood lactate concentrations.

There are conflicting results concerning the effect of $\mathrm{Mg}$ on the blood glucose concentrations in the pig. In agreement with the present results, Porta et al. (1991) demonstrated that feeding rats high levels $(9,000 \mathrm{mg} / \mathrm{kg} \mathrm{Mg})$ of supplemental $\mathrm{Mg}$ aspartate did not alter blood glucose concentrations. Geesink et al. (2004) and Peeters et al. (2006) reported that there were no differences in blood glucose between the control and $\mathrm{Mg}$-supplemented pigs at slaughter. Haenni et al. (1998) reported no relationship between elevated blood $\mathrm{Mg}$ levels and glucose disappearance during a glucose tolerance test. However, Otten et al. $(1993,1995)$ reported that feeding pigs $\mathrm{Mg}$ fumarate from 30 to $100 \mathrm{~kg} \mathrm{BW}$ significantly lowered plasma glucose concentrations.

\section{Muscle energy metabolism}

Muscle glycogen and lactate reflect changes in muscle energy metabolism. Muscle lactate concentration increased as storage time increased, while the opposite trend was detected for glycogen level, which indicated the postmortem energy metabolism of muscles converts glycogen into lactic acid through the glycolytic pathway (Kylä-Puhju et al., 2004). An acute stressor such as negative handling of pigs just prior to slaughter has been shown to increase muscle glycogenolysis (Grandin, 1980). In the present experiment, dietary $\mathrm{Mg}$ acetate and $\mathrm{Mg}$ sulfate supplementation in pigs elevated muscle glycogen and reduced muscle lactate concentration, especially during the first $2 \mathrm{~d}$ of display, compared with pigs fed the control diet, which indicated that $\mathrm{Mg}$ delay the initiation of glycolysis by maintaining high energy phosphates postmortem (Moesgaard et al., 1993). The concentrations of glycogen and lactate in muscle were similar between pigs fed the control diet, $\mathrm{Mg}$ acetate diet and $\mathrm{Mg}$ sulfate diet at the end of storage. This result may indicate that the effect of $\mathrm{Mg}$ acetate and $\mathrm{Mg}$ sulfate on glycolysis or muscle energy metabolism occurs during relatively short periods of displayed storage (about $2 \mathrm{~d}$ after slaughter), and the effect is less noticeable during longer periods of storage.

Because $\mathrm{Mg}$ is involved in the activation of several metabolic enzymes, Heaton (1973) concluded that increasing cellular $\mathrm{Mg}$ concentrations would result in greater energy utilization and efficiency. In the present study, pigs fed the Mg supplemented diets had less lactate accumulation in muscle suggest less glycolysis occurred 
and more glycogen reserves compared with pigs fed the control diet. This might be one of the reasons why $\mathrm{Mg}$ improved meat quality and reduced PSE meat incidence. Similarly, D'Souza et al. (1999) reported that pigs fed Mg diets ( $\mathrm{Mg}$ aspartate, $\mathrm{Mg}$ sulfate and $\mathrm{Mg}$ chloride) had higher muscle glycogen at $5 \mathrm{~min}$ and at $40 \mathrm{~min}$ (except $\mathrm{Mg}$ chloride) post-slaughter and lower muscle lactic acid concentrations in the LT at 5 min post-slaughter compared to pigs fed the control diet. In addition, Lim et al. (2004) also found that supplementing swine diets with $\mathrm{Mg}$ sulfate within 1 wk of slaughter resulted in greater glycogen reserves in the LM. However, D'Souza et al. (2000) and Gaine et al. (2000) reported that supplemental dietary $\mathrm{Mg}$ actually increased muscle lactate concentrations early postmortem. Apple et al. (2005) reported that the LM from pigs fed $2.5 \% \mathrm{Mg}$ mica (MM) increased LM lactate concentrations after transportation stress, and tended ( $\mathrm{p}=$ 0.07 ) to have higher carbohydrate reserves than those fed $0.0 \%$ MM. O'Quinn et al. (2000) failed to detect an effect of supplementary $\mathrm{Mg}$ on LM lactate. The conflicting reports on Mg-supplementation may be related to $\mathrm{Mg}$ sources, genotype and pre-slaughter handling of pigs.

\section{Magnesium and halothane gene}

The scientific literature on the characteristics of heterozygous pigs $(\mathrm{Nn})$ is more controversial. Experiments have confirmed the intermediate position of pigs heterozygous for the HAL gene, as compared with normal and HAL sensitive animals, in terms of post mortem changes in muscle and related quality traits such as meat color, drip loss and sensory-evaluated tenderness (Channon et al., 2000; Fernandez et al., 2002). Studies indicate that halothane carriers $(\mathrm{Nn})$ do have certain advantages compared with halothane negative $(\mathrm{NN})$ pigs such as better feed efficiency, greater carcass yield and higher carcass lean contents (Fisher et al., 2000; Fàbrega et al., 2002). However, these effects were linked to a higher incidence of PSE meat.

The incorporation of supplemental magnesium into animal diets has traditionally been used to prevent the metabolic disorders associated with $\mathrm{Mg}$ deficiency (Littledike et al., 1983). However, recent information implied that the magnitude of responses to $\mathrm{Mg}$ treatment on pork quality may be related to the stress susceptibility, or resistance, of the pigs in the experiments (Caine et al., 2000; Apple et al., 2002; Panella-Riera et al., 2008; 2009). Campion et al. (1971) reported that the initial and ultimate muscle $\mathrm{pH}$ was greater in stress-susceptible pigs intravenously infused with $\mathrm{Mg}$ chloride immediately before slaughter, but the muscle $\mathrm{pH}$ was unaffected by $\mathrm{Mg}$ infusion in stress-resistant pigs. Schmitten et al. (1984) discovered that inclusion of $\mathrm{Mg}$ aspartate in swine finishing diets resulted in improvements in pork color and moisture retention in halothane-positive pigs rather than halothanenegative pigs. Moreover, Schaefer et al. (1993) reported that pork color and water-holding capacity had been improved by dietary $\mathrm{Mg}$ aspartate only in heterozygous carriers of the halothane gene. Similarly, our data concluded that dietary $\mathrm{Mg}$ supplementation improved blood stress indices and muscle energy metabolism of heterozygous carriers of the halothane gene. However, Apple et al. (2002) observed that neither stress response nor postmortem muscle metabolism of halothane-carrier pigs were affected by dietary MM when the pigs were well rested before slaughter.

\section{CONCLUSION}

Supplementation with different $\mathrm{Mg}$ sources (Mg sulfate and $\mathrm{Mg}$ acetate) during the last five days before slaughter improves stress response of halothane-carrier pigs by decreasing serum $\mathrm{CK}$ and lactate concentrations. On the other hand, results of this study suggest that supplementation of halothane-carrier pigs diets with $\mathrm{Mg}$ sulfate and $\mathrm{Mg}$ acetate may be effective in delaying the initiation of glycolysis by elevating muscle glycogen and reducing muscle lactate concentrations. Furthermore, other sources of $\mathrm{Mg}$ should be considered for further studies, with the aim of reducing stress before slaughter and being able to reduce the negative effect of the use of the halothane gene.

\section{ACKNOWLEDGEMENTS}

This work was funded by National Key Technology R\&D Program in the 12th Five plan of China (Nos.2011BAD28B01-02) and part by Key Program from Liaoning (Nos. 2011202005 and 2011215016) .

\section{REFERENCES}

Alonso, V., L. Provincial, M. Gil, E. Guillén, P. Roncalés and J. A. Beltrán. 2012. The impact of short-term feeding of magnesium supplements on the quality of pork packaged in modified atmosphere. Meat Sci. 90:52-59.

Apple, J. K., C. V. Maxwell, B. deRodas, H. B. Watson and Z. B. Johnson. 2000. Effect of magnesium mica on performance and carcass quality of growing- finishing swine. J. Anim. Sci. 78: 2135-2143.

Apple, J. K., C. V. Maxwell, M. R. Stivarius, L. K. Rakes and Z. B. Johnson. 2002. Effect of dietary magnesium and halothane genotype on performance and carcass traits of growingfinishing swine. Livest. Prod. Sci. 76:103-113.

Apple, J. K., E. B. Kegley, C. V. Maxwell, L. K. Rakes, D. Galloway and T. J. Wistuba. 2005. Effects of dietary magnesium and short-duration transportation on stress response, postmortem muscle metabolism, and meat quality of finishing swine. J. Anim. Sci. 83:1633-1645.

Bergmeyer, H. U. 1974. Methods of enzymatic analysis. Academic 
Press, New York, New York, USA.

Brandt, R. H., S. A. Seigle, M. G. Waters and M. H. Bloch. 1980. Spectrophotometric assay for D (-) lactate in plasma. Anal. Biochem. 102:39-46.

Caine, W. R., A. L. Schaefer, J. L.Aalhus and M. E. R. Dugan. 2000. Behaviour, growth performance and pork quality of pigs differing in porcine stress syndrome genotype receiving dietary magnesium aspartate hydrochloride. Can. J. Anim. Sci. 80: 175-182.

Campion, D. R., B. B. Marsh, G. R. Schmidt, R. G. Cassens, R. G. Kauffman and E. J. Briskey. 1971. Use of whole-body perfusion in the study of muscle glycolysis. J. Food Sci. 36:545-548.

Channon, H. A., A. M. Payne and R. D. Warner. 2000. Halothane genotype, pre-slaughter handling and stunning method all influence pork quality. Meat Sci. 56:291-299.

Dalrymple, R. H. and R. Hamm. 1973. A method for the extraction of glycogen and metabolites from a single muscle sample. J. Food Technol. 8:439-444.

D'Souza, D. N., R. D. Warner, B. J. Jeury and F. R. Dunshea. 2000. The influence of dietary magnesium supplement type, and supplementation dose and duration, on pork quality and the incidence of PSE pork. Aust. J. Agric. Res. 51:185-189.

D'Souza, D. N., R. D. Warner, F. R. Dunshea and B. J. Leury. 1999. Comparison of different dietary magnesium supplements on pork quality. Meat Sci. 51:221 -225.

Fàbrega, E., X. Manteca, J. Font, M. Gispert, D. Carrión, A. Velarde, J. L. Ruiz-de-la-Torre and A. Diestre. 2002. Effects of halothane gene and pre-slaughter treatment on meat quality and welfare from two pig crosses. Meat Sci. 62:463-472.

Fàbrega, E., X. Manteca, J. Font, M. Gispert, D. Carrio'n, A. Velarde, J. L. Ruiz-de-la-Torre and A. Diestre. 2004. A comparison of halothane homozygous negative and positive pietrain sire lines in relation to carcass and meat quality and welfare traits. Meat Sci. 66:777-787.

Fernandez, X., E. Neyraud, T. Astruc and V. Sante. 2002. Effects of halothane genotype and pre-slaughter treatment on pig meat quality: 1. Post mortem metabolism, meat quality indicators and sensory traits of m. Longissimus lumborum. Meat Sci. 62:429-437.

Fisher, P., F. D. Mellet and L. C. Hoffman. 2000. Halothane genotype and pork quality. 1. Carcass and meat quality characteristics of three halothane genotypes. Meat Sci. 54:97105.

Frederick, B. R., E. van Heugten and M. T. See. 2006. Effects of pig age at market weight and magnesium supplementation through drinking water on pork quality. J. Anim. Sci. 84:15121519.

Fujii, J., K. Otsu, F. Zorzato, S. De Leon, V. K. Khanna, J. Weiler, P. J. O'Brien and D. H. Maclennan. 1991. Identification of a mutation in the porcine ryanodine-receptor that is associated with malignant hyperthermia. Sci. 253:448-451.

Geesink, G.H., R. G. C. van Buren, B. Savenije, M. W. A. Verstegen, B. J. Ducro, J. G. P. van der Palen and G. Hemke. 2004. Short-term feeding strategies and pork quality. Meat Sci. 67:1-6.

Gispert, M., L. Faucitano, M. A. Oliver, M. D. Guardia, C. Coll, K. Siggens, K. Harvey and A. Diestre. 2000. A survey of pre- slaughter conditions, halothane gene frequency and carcass and meat quality in five Spanish pig commercial abattoirs. Meat Sci. 55:97-106.

Grandin, T. 1980. The effect of stress on livestock and meat quality prior to an during slaughter. Int. J. Study Anim. Probl. $1: 313$.

Hamilton D. N., M. Ellis, M. D. Hemann, F. K. McKeith, K. D. Miller and K. W. Purser. 2002. The impact of longissimus glycolytic potential and short-term feeding of magnesium sulfate heptahydrate before slaughter on carcass characteristics and pork quality. J. Anim. Sci. 80: 1586-1592.

Haenni, A., M. Öhrvalla and H. Lithell. 1998. Atherogenic lipid fractions are related to ionized magnesium status. Am. J. Clin. Nutr. 67:202-207.

Heaton, F. W. 1973. Magnesium requirement for enzymes and hormones. Biochem. Soc. Trans. 1:67-70.

Jensen, P. and P. A. Barton-Gade. 1985. Performance and carcass characteristics with known genotypes for halothane susceptibility. In: European Association of Animal Production Publication (Ed. J. B. Ludvigsen). Pudoc, Wageningen, The Netherlands. pp. 80-87.

Kietzmann, M. and H. Jablonski. 1985. Blocking of stress in swine with magnesium aspartate hydrochloride. Prakt. Tierarzt. 661: 331

Kuhn, G., A. Nowak, E. Otto, V. Albrecht, B. Gassmann, E. Sandner, H. Przybilski and L. Zahn. 1981. Studies on the control of meat quality by special treatment of swine. 1 . Effects of stress and preventative magnesium feeding on selected parameters of carcass value and blood serum. Archiv. für Tierzuckt. 24:217-225.

Kylä-Puhju, M., M. Ruusunen, R. Kivikari, and E. Puolanne. 2004. The buffering capacity of porcine muscles. Meat Sci. 67:587593

Lim, J. S., M. S. Yun, C. S. Kong and Y. Y. Kim. 2004. Effect of magnesium sources on pork quality in finishing pigs. J. Amin. Sci. 82(Suppl. 2):63(Abstr.).

Littledike, E. T., J. A. Stuedemann, S. R. Wilkinson and R. L. Horst. 1983. Grass tetany syndrome. In: Role of Magnesium in Animal Nutrition (Ed. J. P. Fontenot, G. E. Bunce, K. E. Weeb, $\mathrm{Jr}$ and V. G. Allen). Virginia Polytechinc Inst. and St. University, Blacksburg, Virginia. pp. 173-197.

Moesgaard, B., I. E. Larsen, B. Quistorff, I. Therkelsen, V. G. Christensen and P. F. Jorgensen. 1993. Effect of dietary magnesium on post mortem phosphocreatine utilization in skeletal muscle of swine: a non-invasive study using 31PNMR spectroscopy. Acta Vet. Scand. 34:397-404.

NRC. 1998. Nutrient Requirements of Swine.10th Ed. National Research Council. Academy Press, Washington, DC, USA.

Oliver, M. A., M. Gispert and A. Diestre. 1993. The effects of breed and halothane sensitivity on pig meat quality. Meat Sci. 35:105-118.

O’Quinn, P. R., J. L. Nelssen, J. A. Unruh, R. D. Goodband, J. C. Woodworth and M. D. Tokach. 2000. Effects of feeding modified tall oil and supplemental potassium and magnesium on growth performance, carcass characteristics, and meat quality of growing- finishing pigs. Can. J. Anim. Sci. 80:43-49.

Otten, W., T. Bergerhoff, A. Berrer, M.Goldberg and H. M. Eichinger. 1993. Effects of a magnesium fumarate 
supplementation on catecholamines, cortisol and blood metabolites in swine. In: Proceedings of the 39th International Congress of Meat Science and technology., Calgary, Alberta, Canada. pp. 82 (Abstr.).

Otten, W., A. Berrer, T. Bergerhoff, M. Goldberg and H. M. Eichinger. 1995. Effects of dietary magnesium fumarate supplementation on blood metabolites and meat quality in swine. Magnesium-Bulletin. 17:91-95.

Panella-Riera, N., A. Dalmau, E. Fàbrega, M. Fonti Furnols, M. Gispert, J. Tibau, J. Soler, A. Velarde, M. A. Oliver and M. Gil. 2008. Effect of supplementation with $\mathrm{MgCO}_{3}$ and Ltryptophan on the welfare and on the carcass and meat quality of two halothane pig genotypes (NN and $\mathrm{nn}$ ). Livest. Sci. 115: 107-117.

Panella-Riera, N., A. Velarde, A. Dalmau, E. Fàbrega, M. Fonti Furnols, M. Gispert, J. Soler, J. Tibau, M. A. Oliver and M. Gil. 2009. Effect of magnesium sulphate and L-tryptophan and genotype on the feed intake, behaviour and meat quality of pigs. Livest. Sci. 124:277-287.

Peeters, E., B. Driessen and R. Geers. 2006. Influence of supplemental magnesium, tryptophan, vitamin $\mathrm{C}$, vitamin $\mathrm{E}$, and herbs on stress responses and pork quality. J. Anim. Sci. 84:1827-1838.

Peeters, E., A. Neyt, F. Beckers, S. M. D. Smet, A. E. Aubert and R. Geers. 2005. Influence of supplemental magnesium, tryptophan, vitamin $\mathrm{C}$, and vitamin $\mathrm{E}$ on stress responses of pigs to vibration. J. Anim. Sci. 83:1568-1580.
Porta, S., W. Emsenhuber, C. Helbig, J. Helbig, H. G. Classen, J. Rauter and P. Slawitch. 1991. Reversed stress response of the eddocrine rat pancreas in $\mathrm{Mg}^{2+}$ depletion. pages In: Magnesium-A Relevant Ion. John Libbey. \& Co., Ltd., London, U. K. pp. 331-336.

Ryan C. N., K. C. Ferdinand, J. Yčas and E. Miller. 2009. Relationship of ethnic origin, gender, and age to blood creatine kinase levels. Am. J. Med. 122:73-78.

Sahin, N., M. Onderci and K. Sahin. 2005. Magnesium proteinate in more protective than magnesium oxide in heat-stressed quail. J. Nutr. 135:1732-1737.

SAS, Institute Inc. 2001. SAS for Windows Release: Version 8.2th edn. SAS Institute Inc., Cary, North Carolina, USA.

Schaefer, A. L., A. C. Murray, A. K. W. Tong, S. D. M. Jones and A. P. Sather. 1993. The effect of ante mortem electrolyte therapy on animal physiology and meat quality in pigs segregating at the halothane gene. Can. J. Anim. Sci. 73:231240.

Schrader, L. and J. Ladewig. 1999. Temporal differences in the responses of the pituitary adrenocortical axis, the sympathoadrenomedullar axis, heart rate, and behaviour to a daily repeated stressor in domestic pig. Physiol. Behav. 66:775-783.

Schmitten, F., H. Jüngst, K. H. Schepers and A. Festerling. 1984. Untersuchungen über die wirkung des magneaiumhaltigen ergäzungsfuttermittels "Cytran ${ }^{\circledR}$ ” auf die fleischbeschaffenheit von streßanfälligen schweinen. Dtsch. Tierz. Wschr. 91:149151. 